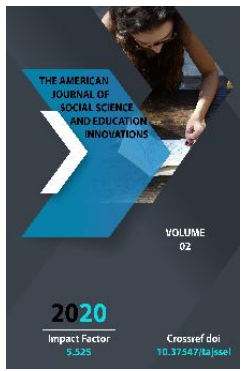

\title{
Arabic Linguistics In Central Asia
}

\author{
Kasimova Sarvinoz \\ (Phd) Lecturer Of Arabic Department, Tashkent State University Of Oriental Studies \\ Uzbekistan
}

Journal Website:

http://usajournalshub.c

om/index,php/tajssei

Copyright: Original

content from this work

may be used under the

terms of the creative

commons attributes

4.0 licence.

\section{ABSTRACT}

Arabic translation which was created in the Middle century can be weird for that means, "the basic tree of knowledge is in Makke but its harvest ripens in Khuroson". However it's essential not to forget that Transoxiana took the main place in Muslim's Asia until the conquering of Mongols. Nishopur was the place where all scientists of Iran and Central Asian gathered and all Transoxianamosques were full of with the students who came far from countries. Samarkand, Bukhara, Urgench were in competition with each other about science and culture for many years, also cities of Transoxiana were ahead of in nature, poems, sarv and nakhv. Central Asian scientists were active in many branches, especially at math, astronomy, medicine history, geography and philology (Arabian, Persian) from VIII century till XIII.

\section{KEYWORDS}

Arabic linguistics, Arabic translation, Middle century, Central Asia, Arabian, Persian.

\section{INTRODUCTION}

It's known that Arabian nomads conquered the cities which got higher culture than them and made them dependent to their own culture , arranged their religion and language in these places. As a result in the forming of Muslim's culture of the Middle Ages it appeared to Arabian -Muslims culture , despite the participation of other representatives of other countries. Usually nomads changed under the influence of local people whom they had conquered before. However, if we pay attention to the history of 
culture of the Arabian, we can see the tendency of keeping their national customs.

Spreading of Islam religion to another countries and the need of learning Arabic language by other nations were the main hit to simplifying its grammar for learning. The utterance which led to clarity the meaning of phrases, compound words, which expressed in Koran oyats, opened the way to learn the poetry as a subject which was created by Islam.

That is why, in Transoxiana not only fiction in local language but also scientific literature in Arabic language were developed. There were written many commentaries on books about Arabic grammar, different dictionaries and poetic prose works. Central Asia took the leading place during the VIII -XII century on behalf of the great contribution to Arabic linguistics of the scientists who came from this land. [20,22]. It's essential to mention the work of scientists such as Avicenna, Abu Rakhon Beruni, Makhmud Koshgariy, Makhmud Zamakhshariy who contributed to Arabic linguistics.

After the independency of Somoni lands from the Central Asia from the $X$ century, most of the big cities became central like Bukhara, Transoxiana, Nishopur and Urgench. I these centers the activity of poet, doctors, scientists and philosophers has been intensified.

As soon as Islam religion come to the territory of Transoxiana in the second half of the VII century, the interests of the scientists and local people to the learning Islam religion have been raised in IX century. Thus was the reason of publishing grammar books and brochures in which the main features of Arabic grammar was explained.
Moreover, Far and Near East countries led the development in the territory of Transoxiana. Many crafted scientists created their work about the theory of Arabic grammar in cities such as Fergana, Kharezm, Karshi, (Nasaf), Bukhara, Samarkand, Forob and Shosh. [14; 33-37].

It is important to mention the work of scientist Abu Raykhon Ibn Akhmad Beruni, who was greatly honored to world's culture in the forming of Arabic linguistic of Transoxiana. [15; 128-131]. He expressed his interest to language and linguistic in his work "Saydana". Well -known medicine man, scientist, poet, musician, great philosopher, physician as well as linguistlbn Sino created the work about phonetics of Arabic language "Asbobu khudud al -khuruf". In this period many scientists honored to the development the school of Arabic linguistic of Transoxiana like specialist of good manners Iskhok Bukhori ( death 206/821), Mukhammad Khorazmi (235/850), Mukhammad Keshi (249/863), Mukhammad Shoshi (291-366/904-976), Akhmad Boysakari (death 320/932), Mukhammad Samarkandi (death 343/954). In this territory studying the issues of Arabic linguistic began from the second half of VIII century and got its peak in the XI century.

Arabic linguistics achieved good results in XII century which was developed in a big rate in the XI century in Transoxiana. After the taking over by Mongols, such impacts of development was still observed in XIII century. However, among the scientists, who worked in the XI century Makhmud Ibn Jarir Zabbi Isfakkhoni Abu Mudarteacher of Makhmud Zamakhshari's, created many works about the Arabic grammar but his works could not be reached to us yet. There is a work about 
morphology of Mukhammad Ibn Ali Ibn Ibrakhim Khorazmi's like "Kitab fi-t-tasrif". (death 425-1034). Nasr Iskhok Bukhori [16;2226] (death 405/1014) who was from Bukhara wrote grammatical brochure about introduction to "Sibavaykhi".

Abulkosim Makhmud ibn Umar ibn Akhmad Zamakhshariy, who honored with his scientific heritage to the development of world subject and culture, in his entire life wrote about seventy priceless work in the sphere of linguistics, history of literature, lexicography, geography and logic. There ten research work of this scientist about linguistic and among them "Al mufassal " is considered one of the best in his research work. Zamakhshariy was the member of Bagdod School. It is clear that most of the researchers of Bogdod School were busy with the science, therefore, all their utterances led them to express clearly grammar rules of Arabic language $[8,40]$.

That is why his work "Mufassal" is considered one of the best classical works with its meaning and clearness. After the work of Sibavaykhi Book it is found one of the famous work and important research work and its author was one of the best about grammar among them. [19, 3]. "Mufassal" was one of the great work about grammar in Rome and Surry. At that period although there were many books about Arabic grammar, there was need to create grammatical complex, detailed research works. Thus, members of literature had to address to the scientist Zamakhshariy who was not Arabian but had good knowledge in Arabic language.

In Kharezm Scientist in Arabic language and represented of aruz science Abul Khasan Ali ibn Arrak Khorazmiy (death 583/1143), assistance of Makhmud Zamakhshariy Ali ibn Mukhammad Umraniy Khorazmiy (death 560/1164), Mukhammad ibn Abul Kosim Bayjuk Khorazmiy (death 562/1166), and Abul Muyyad Akhmad Makkiy (death 568/ 1172) worked at this period. [15.,128-131].

It is certain to mention the work of Al-khasan Katton Marvaziy Bukhoriy about science, gender and linguistics, who worked in Bukhara. [16,22-26].

In this period linguists of Fergana were also active in doing research works about Arabic grammar. Among the scientists of this country, linguists, historian and poet Mukhammad Akhsikatiy (death 520/1126), grammar researcher, poet Akhmad Ahsikatiy Abu Rashid (466-538/1)7-1133), chemistries, philosopher, doctor and linguists Asiriddin Axsikatiylars' (501-594/1108-1198) research papers take great attention. [14, 33-37]

In this period in Nasaf Abul Xavs Nasafiy (460535,1068-1133) and Umar Nasafiy (461537,1069-1142) did their research work about Arabic linguistics. Umar Nasafiy's work "Issues of linguistics" was very famous.

In the beginning of XIII century in Kharezm Nasr ibn Abu Sayd Ali Abul Fatx Mutarriziy (538-610,1044-1213), who was called like an assistant of Zamaxshariy, created his linguistic works like "Al-Mukaddimatul-Muyrriziyafk-nnaxv", “Al-lki a fk-l-luga”, "Al-miybakhfk-nnavx". Scholar of Arabic grammar Kosim ibn Khudsayn Mukhammad Khorazmiy (565-616, 1160-1219) created works about sarv, outer flexi and syntactics, but most of them were not reached to us. Yusuf ibn Abu Bakr ibn Mukhammad Sakkokiy Kharazmiy (565-627, 1160-1229), who wrote description to the work “Mufassal”, “Unmuzaj” by scholar 
Zamakhshariy, became well-known with its work “Miftakhul-ulum”.

In Bukhara Khamiduddin Daririy Bukhoriy held on his activity and wrote some works about the grammar of Arabic language, aruz and fikh.(666/1267). K. Brokkelman mentioned in his work that Dariry's works "Muqaddima" "Kitabul-aphu" nowadays are still being kept in Berlin library, and there was written description to the work "Al Gaya" of Abu Bakr Nishopur. That is why, Daririy wrote his first description to the work of Burkhonuddin Marginoniy Khanafiy's (died in 593 year) الـ له ايد "Al-Khidaya" which consist of two parts and called ئ دال فوا "Al-Favaid" ("Useful thing").[22, 2]. This description consists of two parts which help to clarify complex parts of the work.

As we look though the research works which were done in Transoxiana in the XI and XIII century, we can be aware of those linguists, who were from Bukhara and Khorezm, worked effectively. Until this period and later on scientists, who were from Samarkand and did their research work, just did not work effectively during the period of culture civilization, but one of the crafted scientist Masud Taftazoniy (712-791,1312-1389) made his great contribution in grammar, morphology and the rights of Islam sphere in the XIV century.

It is clear from the analysis of scientific resources that not only linguists of Forob and Shosh were active in the XI century, but also in the XII century linguists of Nasaf and Fergana were active in explaining of Arabic grammar.

Research works, which were done about Arabic linguistics, can be divided into two types: theoretical and practical. Zamaxsharis's work "Mufassal" belongs to theoretical type. Most of the linguists address to this work to solve some complicated issues about grammar. We had mentioned before that scientist used the extraordinary way of expressing Arabic grammar in his work "Mufassal" . This work consists of four sections; firstly the author divided the words in Arabic language into three sections according its parts of speech (name, verb, auxiliary word) and in these sections he observed the grammatical issues which mainly specialized to the certain parts of speech; in the fourth section phonetics of Arabic language as well as phonology issues have been explained. In introduction part of the work it is mentioned that it is necessary to learn Arabic language grammar dividing it into name, verb and auxiliary words; firstly - in name section description is given to the situation of flexi.

In the second section of the work Zamaxshariy explained actions of verbs to its past, present and future tense, moods, active and passive voices, transitive and intransitive verbs, auxiliary verbs, insulting, surprising verbs and three or four syllable verbs. In the third section some issues about interjections, conjunctions, transitions and suffixes which show variety functions have been researched.

Other phonetic issues, which belonged to all three sectionsbut were not discussed yet, are described in the fourth section of the work. There stops of the sound,omitting the sound which is expressed with khamza, coming together of two consonant letters, reading of the words which began with the consonant letter, adding of the suffixes, interchanging of letters, gradations rules of sick letters, 
addition of the same letters' rules have been explained.

Thus expression of issues of Arabic grammar cannot express functional interchanges of parts of speech and mutual dependency which is only connected with this language. Therefore, Zamakhshariy used the style which was not used in the traditions of Arabian linguistics and for the first time he showed "Mukaddima" in his work as well as by means of dependency explanation between the parts of speech he honored greatly to the development of Arabic grammar. Because such kind of new approach was the reason of appearing new terminology and rules in Arabic language grammar.

"Unmuzaj” by Zamakhshariy, "Miskhob” by Mutarriziy, and "Mukaddima" by Daririy's pamphlets are considered to have practical character.

"Unmuzaj" pamphlet is specialized for studying Arabic language, Zamakhshari created this pamphlet shorter and briefly than "Mufassal”. "Miskhob" by Mutarriziy, and "Mukaddima" by Daririy'spamphlets are also specialized for studying and there expression of grammar style is different. Zamakhshariy divided the themes of Arabic grammar into name, verb and letter sections and studied them separately, but Daririy did not distinguish them into groups and explained them in its style. As we mentioned before Daririy in his book "Mukaddima" showed the parts of speech of the Arabic language, then explained one after another flexi, initial name (subject) and its attribute (predicate), however, verb and particle which impact to these parts, the usage of cases, subordinate words, grammar categories, abbreviation words, not completely declining themes. Such approaches of Daririy in explaining themes are also pursued in the work of "Al-Kitab" of Sibavakhi and in his followers work "lydokh" of Abu Ali Khasan Farisiy (died in 987). [10;17]. Many of the navkh people also have used this type of style to show the specialty of Arabic grammar.

NosirMutarriziyalso wrote his pamphlet named "Misbokh", which was clear and briefly and consisted of five chapters, that was written by the help of used style in Jurjoniy's work called "Avamilu-Imi'a" and he followed the practice about education of baghdod linguists. Mutarriziy remembered the work "Avamilu-Imi'a"in the introduction part of the third chapter of "Misbokh" as following:

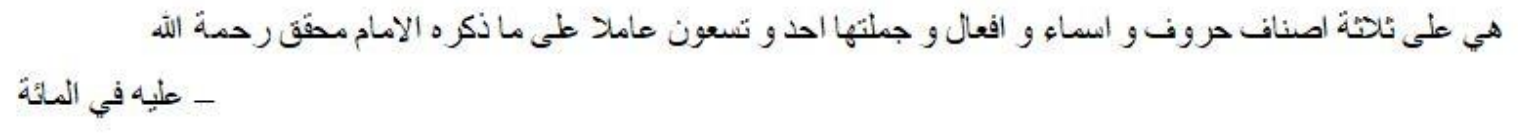

They that reasons will be in three types: auxiliary words, names and verbs, as Imam (let Allah make him in peace) mentioned in his work named "Mi'a", there number is 91 almost. By the following this style, every grammatical issues in Arabic language has been studied according to certain facts. The first section of the work is devoted to the 
grammatical terms, the second one fact in criterions (that grammatical issues which occurs based on some rules), the third section oral factors (during the many years has been used in oral speech and became the certain one), the fourth section meaningful factors and the fifth section is dedicated to learn grammatical issues which were only specialized in Arabic language.

\section{CONCLUSION}

It is essential to say in conclusion that analyzing the research work which were done about Arabic linguistics in XI-XIII century in Transoxiana, especially, shows that lexicography of Arabic language, lexicology, theoretical basis of its grammar have been investigated.

\section{REFERENCES}

1. Akhvlediani V.G. Avicenna's Phonetic Treatise. - Tbilisi, 1966.

2. Akhvlediani V.G. Arabic linguistics of the Middle Ages. History of linguistic teachings. Medieval East. - L., 1981.

3. Bartold V.V. Muslim Renaissance scholars. Op. T. VI. - M .: Nauka, 1966 .- 784 p.

4. Belkin V.M. Arabic lexicology. - M .: MGU., 1961 .- 200 p.

5. Belova A.G. History of the Arabic language. - M .: Nauka, 1979 .- 218 p.

6. Berezin F.M. History of linguistic teachings. - M .: Higher school, 1975 .-$304 \mathrm{p}$.

7. Questions of oriental literary criticism and textual criticism. - Moscow: Nauka, 1975 -- $244 \mathrm{p}$.

8. Gabuchan G.M. On the question of Arabic grammatical teachings. Semitic languages, collection of articles. - M., 1963.
9. Gamal L. Fundamentals of word classification in Arabic and Russian grammatical traditions: Author's abstract. diss. ... Cand. philol. sciences. - M., 1975.

10. Girgas V. Sketch of the grammatical system of the Arabs. -SPb .: Printing house of the Imperial Academy of Sciences, 1873. - 203 p.

11. Grande B.M. Arabic grammar course in comparative history. - $\mathrm{M}$.: Izd.vost.lit., 1963 .- 593 p.

12. Zvegintsev V.A. History of Arabic linguistics. Brief sketch. $-\mathrm{M}$ : Moscow State University, 1958. - $80 \mathrm{p}$.

13. Zokirov Sh. Arabic-language sources of the 9th-12th centuries. and their importance in the study of the ethnopolitical life of the peoples of Central Asia (Turkic-speaking peoples): Diss. ... Cand. history. sciences. Tashkent, 1994 --- 190p.

14. Nosirova M. Movarounnaarda Arab tilshunosligi. Masalalari philology. - T .: Jahon Tillari Universiteti, 2011. - No. 4. B.33-37.

15. Nosirova M. Orta asrlard Khorazmda Arab tilshunosligi // Ta'lim tizimida Izhtimoyhumanitarian fanlar. - Toshkent: University Engineering. - 2010. - No. 1. B.128-131.

16. Nosirova M. Bukhorova Samargandning Orta asr tilshunoslari / Ilmiy-tauliliy akhborot. TIU. - 2010. - No. 1. - B. 22-26.

17. Nosirova M.A., Turdialiev B. Arab tilida ega va kesm category. - T., 2007 .-- 116 p.

18. Robakidze N. Phonetic concept of azZamakhshari: Author's abstract. diss. ... Cand. philol. sciences. - Tbilisi, 1984 .-- 22 p. 
19. Samiroiy F. Ad-Dirasa an-naxwiyya wa-llufaviya inda az-Zamakhshariy. - Bafdod, 1971.

20. Frolov D. Arabic philology. - M., 2006.
21. Richard Burton. Sindh and the Races That Inhabit the Valley of the Indus. -New Delhi, 1996.

1. 1981 حاجى خليفة. كتنف الظنون عن اسامى الكنب و الفنون. بيروت.

Қўлёзма манбалар:

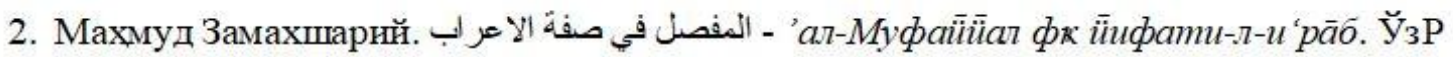
ФАШИ. Кўлёзма №5198. - 1357 й.

3. Носир Мутарризий. حتاب المصباح - Кита̄бy-л-мийба̄ну. ЎзР ФАШИ. Кўлёзма №3312/5.

4. Хамндуддин Даририй. Мукаддима. ضريزي - Uаририй”. ЎзФАШИ. Кўлёзма №6452. -11 в. 1284 й.

5. http://shamela.ws

6. http://ar.wikipedia.org 